\title{
Description of Kushneria aurantia gen. nov., sp. nov., a novel member of the family Halomonadaceae, and a proposal for reclassification of Halomonas marisflavi as Kushneria marisflavi comb. nov., of Halomonas indalinina as Kushneria indalinina comb. nov. and of Halomonas avicenniae as Kushneria avicenniae comb. nov.
}

Correspondence Antonio Ventosa ventosa@us.es

\author{
Cristina Sánchez-Porro, ${ }^{1}$ Rafael R. de la Haba, ${ }^{1}$ Nelis Soto-Ramírez, ${ }^{2}$ \\ M. Carmen Márquez, ${ }^{1}$ Rafael Montalvo-Rodríguez ${ }^{2}$ and Antonio Ventosa ${ }^{1}$ \\ ${ }^{1}$ Department of Microbiology and Parasitology, Faculty of Pharmacy, University of Sevilla, \\ 41012 Sevilla, Spain \\ ${ }^{2}$ Biology Department, Box 9012, University of Puerto Rico, Mayagüez 00681, Puerto Rico
}

An aerobic, moderately halophilic, Gram-negative, motile, non-sporulating rod-shaped bacterium, designated strain $\mathrm{A} 10^{\top}$, was isolated from the surface of leaves of the black mangrove Avicennia germinans and was subjected to a polyphasic taxonomic study. Strain $\mathrm{A} 10^{\top}$ was able to grow at $\mathrm{NaCl}$ concentrations in the range 5-17.5\% (w/v) with optimum growth at $10 \%(\mathrm{w} / \mathrm{v}) \mathrm{NaCl}$. Growth occurred at temperatures of $20-40{ }^{\circ} \mathrm{C}$ (optimal growth at $37{ }^{\circ} \mathrm{C}$ ) and $\mathrm{pH} 5.5-8.5$ (optimal growth at $\mathrm{pH}$ 7.0-8.0). The major respiratory quinone was ubiquinone 9 . The major fatty acids were $\mathrm{C}_{16: 0}, \mathrm{C}_{18: 1} \omega 7 c, \mathrm{C}_{19: 0}$ cyclo $\omega 8 c$ and $\mathrm{C}_{12: 0} 3-\mathrm{OH}$. The polar lipids were phosphatidylglycerol, diphosphatidylglycerol, phosphatidylethanolamine, and unidentified phospholipids, glycolipids and an aminoglycolipid. Phylogenetic analysis based on 16S rRNA gene sequence comparisons revealed that strain $A 10^{\top}$ is closely related to Halomonas avicenniae MW2a ${ }^{\top}$ (95.7 \% sequence similarity), Halomonas marisflavi SW32 ${ }^{\top}$ (95.2\%) and Halomonas indalinina $\mathrm{GC} 2.1^{\top}$ (95.0\%). Strain $A 10^{\top}$ formed a coherent phylogenetic branch with these three species, separated from other species of Halomonas and closely related genera (with 16S rRNA gene sequence similarities below $94.0 \%$ ). A complete $23 S$ rRNA gene sequence comparison of strain $A 10^{\top}$ with closely related species confirmed the phylogenetic position of the novel isolate, forming a branch with the species Halomonas avicenniae, Halomonas indalinina and Halomonas marisflavi, separated from other species of the genera belonging to the family Halomonadaceae (showing sequence similarities below 91.7\%). DNA-DNA hybridization studies between strain $\mathrm{A} 10^{\top}$ and Halomonas avicenniae MW2a ${ }^{\top}$, Halomonas marisflavi DSM $15357^{\top}$ and Halomonas indalinina $\mathrm{CG} 2.1^{\top}$ were 21,17 and $10 \%$, respectively. These levels of DNA-DNA relatedness were low enough to classify strain $A 10^{\top}$ as representing a genotypically distinct species. Overall, the phenotypic, genotypic, chemotaxonomic and phylogenetic results demonstrated that strain $\mathrm{A} 10^{\top}$ represents a new genus and species. The name Kushneria aurantia gen. nov., sp. nov. is proposed, with strain $A 10^{\top}$ ( $=$ CCM $7415^{\top}=$ CECT $7220^{\top}$ ) as the type strain. This is the type species of the new proposed genus, which belongs to the family Halomonadaceae. In addition, our data support the placement of the species Halomonas marisflavi, Halomonas indalinina and Halomonas avicenniae within this new genus, as Kushneria marisflavi comb. nov., Kushneria indalinina comb. nov. and Kushneria avicenniae comb. nov., respectively. 
The family Halomonadaceae, in the class Gammaproteobacteria, was proposed by Franzmann et al. (1988) and, at the time of writing, includes a large number of species within seven genera: Halomonas (type genus), Carnimonas, Chromohalobacter, Cobetia, Halotalea, Modicisalibacter and Zymobacter (Vreeland et al., 1980; Ventosa et al., 1989; Okamoto et al., 1993; Garriga et al., 1998; Arahal et al., 2002a; Arahal \& Ventosa, 2005; Ntougias et al., 2007; Ben Ali Gam et al., 2007). Most genera have a single species, and only Chromohalobacter (9 species) and Halomonas (49 species) have more than one species. The genus Halomonas includes Gram-negative bacteria mainly with a respiratory type of metabolism, and most species that have been isolated from marine or hypersaline environments (salterns, saline lakes, saline soils, salted foods, etc.) are halophilic (Arahal \& Ventosa 2005; Arahal et al., 2007; Vreeland, 2005). This genus is very heterogeneous, as reflected by the broad range of phenotypic features of the species that it includes (Mata et al., 2002), or the wide range of $\mathrm{G}+\mathrm{C}$ content of their DNA (52-68 mol\%; Vreeland, 2005). Arahal et al. (2002b) carried out a phylogenetic study of the family Halomonadaceae, based on a comparison of the complete $16 \mathrm{~S}$ rRNA and $23 \mathrm{~S}$ rRNA gene sequences, and they established that the genus Halomonas is not monophyletic; it comprises two main clusters of species as well as several species that do not cluster consistently.

Recently, we have investigated the microbiota of Avicennia germinans, a mangrove that is able to secrete salt crystals onto the surface of its leaves when the salt concentration is in excess of that normally present in the vascular system (Lugo \& Snedaker, 1975). As a result we described two novel bacterial species, Halomonas avicenniae (SotoRamírez et al., 2007) and Halobacillus mangrovi (SotoRamírez et al., 2008). In the present study, we determined the taxonomic position of strain $\mathrm{A} 10^{\mathrm{T}}$, a novel organism isolated from the surface of leaves of the black mangrove, which is closely related to the species Halomonas marisflavi (Yoon et al., 2001), and the recently described species Halomonas indalinina (Cabrera et al., 2007) and Halomonas avicenniae (Soto-Ramírez et al., 2007). Our results show that the novel bacterium constitutes a novel species of a new genus, for which we propose the name Kushneria aurantia gen. nov., sp. nov. In addition, we propose the reclassification within this new genus of these three closely related species previously assigned to the genus Halomonas.

Strain $\mathrm{A} 10^{\mathrm{T}}$ was isolated from the surface of leaves of the black mangrove. For isolation, a total of 40 leaves were collected randomly from four $A$. germinans trees growing near the solar salterns of Cabo Rojo, Puerto Rico. These leaves were placed in sterile bags (Whirl Pak) containing $1 \%$ phosphate buffer ( $\mathrm{pH} 7.0)$ with $15 \%(\mathrm{w} / \mathrm{v}) \mathrm{NaCl}$ and mixed. This procedure allowed the suspension of the micro-organisms present in the salt crystals and on the surface of the leaves. Ten millilitres of the mix were then used for serial dilutions. The dilutions were poured onto agar plates containing Sehgal-Gibbons medium at $10 \%$ (w/v) $\mathrm{NaCl}$ (Sehgal \& Gibbons, 1960). The inoculated plates were incubated at $30{ }^{\circ} \mathrm{C}$. After 3 days of incubation, colonies were selected and purified by using the quadrant streak plate method.

The following reference strains were used in this study: Halomonas avicenniae MW2 $\mathrm{a}^{\mathrm{T}}$, Halomonas marisflavi DSM $15357^{\mathrm{T}}$, Halomonas indalinina CG2.1 ${ }^{\mathrm{T}}$ and Halomonas elongata ATCC $33173^{\mathrm{T}}$. They were cultivated in SW10 medium with $10 \%(\mathrm{w} / \mathrm{v})$ total salts $[8.1 \% \mathrm{NaCl}, 0.7 \%$ $\mathrm{MgCl}_{2}, 0.96 \% \mathrm{MgSO}_{4}, 0.036 \% \mathrm{CaCl}_{2}, 0.2 \% \mathrm{KCl}, 0.006 \%$ $\mathrm{NaHCO}_{3}, 0.0026 \% \mathrm{NaBr}, 0.5 \%$ yeast extract (Difco)] (Nieto et al., 1989). The $\mathrm{pH}$ was adjusted to 7.2 with $1 \mathrm{M}$ $\mathrm{KOH}$. Where necessary, solid media were prepared by adding $2.0 \%(\mathrm{w} / \mathrm{v})$ Bacto-agar (Difco).

The optimal conditions for growth were determined by growing strain $\mathrm{A}^{\mathrm{T}} 0^{\mathrm{T}}$ in $\mathrm{SW}$ medium at $0,2.5,5,7.5,10$, $12.5,15,17.5,20,25$ and $30 \%(\mathrm{w} / \mathrm{v})$ total salts as well as in this medium but with only $\mathrm{NaCl}$ instead of the salt mixture described above, and at temperatures of $4,15,20,25,30$, 37,40 and $42{ }^{\circ} \mathrm{C}$. The $\mathrm{pH}$ range for the isolate was tested in SW10 medium adjusted to the following $\mathrm{pH}$ values: 4.0, 5.0, 6.0, 7.0, 8.0, 8.5 and 9.0, with the addition of the appropriate buffering capacity to each medium. The cells were cultivated with constant agitation (180 r.p.m.) and growth was monitored by measuring absorbance at $600 \mathrm{~nm}$. Cells of strain $\mathrm{A} 10^{\mathrm{T}}$ were Gram-negative, nonspore-forming rods. The cells were $2.0-5.0 \mu \mathrm{m}$ long and $1.0 \mu \mathrm{m}$ wide at the exponential phase of growth in SW10 medium at $37{ }^{\circ} \mathrm{C}$, and were motile. Optimal growth conditions occurred at $10 \%(\mathrm{w} / \mathrm{v})$ total salts or at $10 \%$ (w/v) $\mathrm{NaCl}, 37^{\circ} \mathrm{C}$ and a $\mathrm{pH}$ of $7.0-8.0$. Thus, strain $\mathrm{A} 10^{\mathrm{T}}$ is a moderately halophilic micro-organsim (Ventosa et al., 1998).

To characterize the isolate phenotypically, we followed the recommended minimal standards for describing new taxa of the family Halomonadaceae (Arahal et al., 2007). The phenotypic tests included Gram reaction (Dussault, 1955), cell morphology, motility, catalase and oxidase production, as well as other tests included in the species description. Macroscopic properties were determined using the classical characterization of colony appearance. All biochemical tests were carried out at $10 \%$ total salts and $37{ }^{\circ} \mathrm{C}$, unless stated otherwise. Catalase activity was determined by adding $1 \%(\mathrm{w} / \mathrm{v}) \mathrm{H}_{2} \mathrm{O}_{2}$ solution to colonies on SW10 agar medium. The oxidase test was performed using the Dry Slide Assay (Difco). Hydrolysis of starch, gelatin, tyrosine and Tween 80, and production of urease and phosphatase were determined as described by Cowan \& Steel (1965), with the addition of $10 \%$ total salts to the medium. Citrate utilization was determined on Simmons' citrate medium supplemented with SW10. Acid production from carbohydrates was determined using a phenol red base supplemented with $1 \%$ of the carbohydrate and SW 10 medium. Growth under anaerobic conditions was determined by incubating strain $A 10^{\mathrm{T}}$ in an anaerobic chamber 
in SW10 medium. Further tests for acid production from carbohydrates and enzymes were carried out using API 20 $\mathrm{NE}$ and API ID32E (bioMérieux), inoculated according to the manufacturer's instructions using inoculated fluid at $10 \% \mathrm{NaCl}$ and incubation at $37^{\circ} \mathrm{C}$.

To determine the range of substrates used as carbon and energy sources, the classical medium of Koser (1923) as modified by Ventosa et al. (1982) was used, containing $\left(\mathrm{l}^{-1}\right): 75 \mathrm{~g} \mathrm{NaCl}, 2 \mathrm{~g} \mathrm{KCl}, 0.2 \mathrm{~g} \mathrm{MgSO}_{4} .7 \mathrm{H}_{2} \mathrm{O}, 1 \mathrm{~g} \mathrm{KNO}_{3}$, $1 \mathrm{~g}\left(\mathrm{NH}_{4}\right)_{2} \mathrm{HPO}_{4}, 0.5 \mathrm{~g} \mathrm{KH}_{2} \mathrm{PO}_{4}$ and $0.05 \mathrm{~g}$ yeast extract (Difco). Substrates were added as filter-sterilized solutions to give a final concentration of $1 \mathrm{~g} \mathrm{l}^{-1}$, except for carbohydrates, which were used at $2 \mathrm{~g} \mathrm{l}^{-1}$. When the substrate was an amino acid, it was tested as carbon, nitrogen and energy sources, and the basal medium was therefore prepared without $\mathrm{KNO}_{3}$ and $\left(\mathrm{NH}_{4}\right)_{2} \mathrm{HPO}_{4}$. Additional nutritional features of the isolate were determined using Biolog MicroPlates. Strain $\mathrm{A} 10^{\mathrm{T}}$ was grown on SW10 medium at $37{ }^{\circ} \mathrm{C}$ for $48 \mathrm{~h}$, and suspended in $10 \%$ $(\mathrm{w} / \mathrm{v}) \mathrm{NaCl}$ solution, within the density range specified by the manufacturer with a Biolog photometer model 21101. Immediately after suspending the cells in the saline solution, the suspensions were transferred into sterile multichannel pipetter reservoirs (Biolog) and the Biolog GN Microplates were inoculated with $125 \mu \mathrm{l}$ of the cell suspension per well by means of an 8-channel repeating pipetter. The inoculated Biolog plates were incubated at
$37{ }^{\circ} \mathrm{C}$ for 7 days and the results were read with a MicroPlate Reader using Microlog 3.59 computer software to perform automated reading. Antibiotic susceptibility was determined according to the conventional Kirby-Bauer method (Bauer et al., 1966). Other characterization methods used have been described in detail by Ventosa et al. (1982) and Quesada et al. (1984). The phenotypic characteristics of strain $\mathrm{A} 10^{\mathrm{T}}$ are given in Table 1 and in the species description.

Chromosomal DNA was isolated and purified according to the method described by Marmur (1961). The 16S rRNA gene was amplified using the universal primers $16 \mathrm{~F} 27$ and 16R1488 as described by Mellado et al. (1995). An almost complete $16 \mathrm{~S}$ rRNA nucleotide sequence of strain $\mathrm{A} 10^{\mathrm{T}}$ was determined by NBT-Newbiotechnics (Sevilla, Spain) using an automated DNA sequencer model 3130XL (Applied Biosystems) and was compared with 16S rRNA reference gene sequences retrieved from GenBank and EMBL databases by BLAST search. Subsequent sequence analysis was conducted using the ARB program package (Ludwig et al., 2004). Following the recommendations of Ludwig et al. (1998), alternative treeing methods (maximum-parsimony, neighbour-joining and maximum-likelihood) were used. A comparison using 16S rRNA gene sequences from databases revealed that the $16 \mathrm{~S}$ rRNA gene sequence $(1428 \mathrm{bp})$ of strain $\mathrm{A} 10^{\mathrm{T}}$ displayed a high level of similarity to those of Halomonas species. The closest relatives were

Table 1. Characteristics that differentiate strain $A 10^{\top}$ from the type strains of Halomonas marisflavi, Halomonas indalinina, Halomonas avicenniae and Halomonas elongata

Strains: $1, \mathrm{~A}^{\mathrm{T}}{ }^{\mathrm{T}}$ (Kushneria aurantia gen. nov., sp. nov.); 2, Halomonas marisflavi KCCM $80003^{\mathrm{T}}$; 3, Halomonas indalinina CG2.1 ${ }^{\mathrm{T}}$; 4 , Halomonas avicenniae MW2a ${ }^{\mathrm{T}} ; 5$, Halomonas elongata ATCC $33173^{\mathrm{T}}$. Data are from Yoon et al. (2001), Cabrera et al. (2007), Soto-Ramírez et al. (2007), Arahal $\&$ Ventosa (2005) and this study. +, Positive; -, negative, \pm , weak reaction.

\begin{tabular}{|c|c|c|c|c|c|}
\hline Characteristic & $1^{*}$ & 2 & 3 & 4 & 5 \\
\hline Cell morphology & Rods & Rods or oval cells & Short rods & Rods or oval cells & Short rods \\
\hline Colony pigmentation & Orange & Yellow & Orange & Orange & Cream \\
\hline $\mathrm{NaCl}$ optimum (\%, w/v) & 10 & $0.5-12$ & $7.5-10$ & 5 & 3-8 \\
\hline $\mathrm{pH}$ range & $5.5-8.5$ & $5.0-10.0$ & $5.0-9.0$ & $5.0-9.0$ & $5.0-10.0$ \\
\hline Temperature range $\left({ }^{\circ} \mathrm{C}\right)$ & $20-40$ & 4-37 & $15-40$ & $12-40$ & $4-45$ \\
\hline $\mathrm{H}_{2} \mathrm{~S}$ production & - & - & - & + & \pm \\
\hline \multicolumn{6}{|l|}{ Acid production from: } \\
\hline L-Arabinose & - & + & + & + & + \\
\hline D-Fructose & + & + & $+^{*}$ & + & - \\
\hline Maltose & + & + & - & \pm & + \\
\hline Mannitol & - & \pm & $-{ }^{*}$ & + & + \\
\hline Urea & - & - & - & - & + \\
\hline DNA G $+\mathrm{C}$ content $(\mathrm{mol} \%)$ & 61.7 & 59.0 & 60.9 & 61.5 & 60.5 \\
\hline
\end{tabular}

${ }^{\star}$ Data from this study. 
Halomonas avicenniae $\mathrm{MW} 2 \mathrm{a}^{\mathrm{T}}$, Halomonas marisflavi DSM $15357^{\mathrm{T}}$ and Halomonas indalinina CG2.1 ${ }^{\mathrm{T}}$, with 95.7, 95.2 and $95.0 \%$ sequence similarities, respectively. Sequence similarity with respect to other Halomonas species was equal to or less than $92.6 \%$; the similarities obtained when strain $\mathrm{A} 10^{\mathrm{T}}$ was compared with other species of the genera Halomonas, Chromohalobacter, Modicisalibacter, Halotalea, Zymobacter, Carnimonas or Cobetia were 92.6-90.7, 93.692.0, 92.5, 91.3, 91.1, 91.0 and $90.9 \%$, respectively. The phylogenetic tree obtained by using the maximumparsimony method showed strain $\mathrm{A} 10^{\mathrm{T}}$ within a cluster constituted by the species Halomonas avicenniae MW $2 \mathrm{a}^{\mathrm{T}}$, Halomonas marisflavi SW $32^{\mathrm{T}}$ and Halomonas indalinina CG2.1 ${ }^{\mathrm{T}}$ (Fig. 1). The tree topology was similar when we used other algorithms (neighbour-joining and maximumlikelihood). Strain $\mathrm{A}^{\mathrm{T}}{ }^{\mathrm{T}}$ and these three Halomonas species were phylogenetically related to Chromohalobacter species (94.0-92.0\% sequence similarity) and to other species of Halomonas (93.8-90.7\%). The similarity values with respect to the genera Modicisalibacter, Halotalea, Zymobacter, Carnimonas and Cobetia were 92.8-92.5\%, 92.8-91.3\%, 93.4-91.1\%, 91.8-91.0\% and 92.6-90.9\%, respectively.

In order to confirm the phylogenetic position of these species, we carried out a phylogenetic study based on a comparison of $23 \mathrm{~S}$ rRNA gene sequences. The $23 \mathrm{~S}$ rRNA gene was amplified using primers designed in this study and others described by Arahal et al. (2002b). An almost complete $23 \mathrm{~S}$ rRNA nucleotide sequence was determined by NBT-Newbiotechnics (Sevilla, Spain) using an automated DNA sequencer model 3130XL (Applied Biosystems). 23S rRNA gene amplification and sequencing primers used are shown in Supplementary Table S1 (available in IJSEM Online). The 23S rRNA gene sequences of strain $\mathrm{A}^{\mathrm{T}} \mathrm{T}^{\mathrm{T}}$, Halomonas avicenniae MW2 $\mathrm{a}^{\mathrm{T}}$, Halomonas marisflavi DSM $15357^{\mathrm{T}}$ and Halomonas indalinina CG2.1 ${ }^{\mathrm{T}}$ were compared with reference $23 \mathrm{~S}$ rRNA gene sequences retrieved from the GenBank and EMBL databases by BLAST search. Subsequently, sequence analysis was performed using the ARB program package (Ludwig et al., 2004). Alternative treeing methods (neighbour-joining, maximum-parsimony and maximum-likelihood) were used for these analyses. Similar to the 16S rRNA gene sequence analysis, the $23 \mathrm{~S}$ rRNA gene sequence $(2914 \mathrm{bp}$ ) of strain $\mathrm{A} 10^{\mathrm{T}}$ displayed a high level of similarity to those of Halomonas avicenniae $\mathrm{MW} 2 \mathrm{a}^{\mathrm{T}}$, Halomonas indalinina CG2.1 $1^{\mathrm{T}}$ and Halomonas marisflavi DSM $15357^{\mathrm{T}}$, with 94.5, 93.6 and $93.5 \%$ gene sequence similarities, respectively. The sequence similarities of strain $\mathrm{A} 0^{\mathrm{T}}$ and other Halomonas species were $90.2-87.6 \%$, whereas when we compared the sequence of strain $\mathrm{A} 10^{\mathrm{T}}$ with those of other related genera the values were $90.1-89.3 \%$ with Chromohalobacter, $89.8 \%$ with Cobetia, $88.8 \%$ with Zymobacter and $88.3 \%$ with Carnimonas. The phylogenetic tree obtained using the maximum-parsimony method showed that strain $\mathrm{A} 10^{\mathrm{T}}$ fell within a cluster constituted by the species Halomonas marisflavi DSM $15357^{\mathrm{T}}$, Halomonas indalinina CG2. $1^{\mathrm{T}}$ and Halomonas avicenniae MW $2 \mathrm{a}^{\mathrm{T}}$ (Fig. 2). When we used the neighbour-joining or maximum-likelihood algorithms the trees obtained were very similar to each other, confirming the stability of the tree topologies. These data confirm that strain $\mathrm{A} 10^{\mathrm{T}}$ and the species Halomonas marisflavi, Halomonas indalinina and Halomonas avicenniae constitute a robust and stable phylogenetic branch within the family Halomonadaceae, sufficiently separated from other species of the genera of

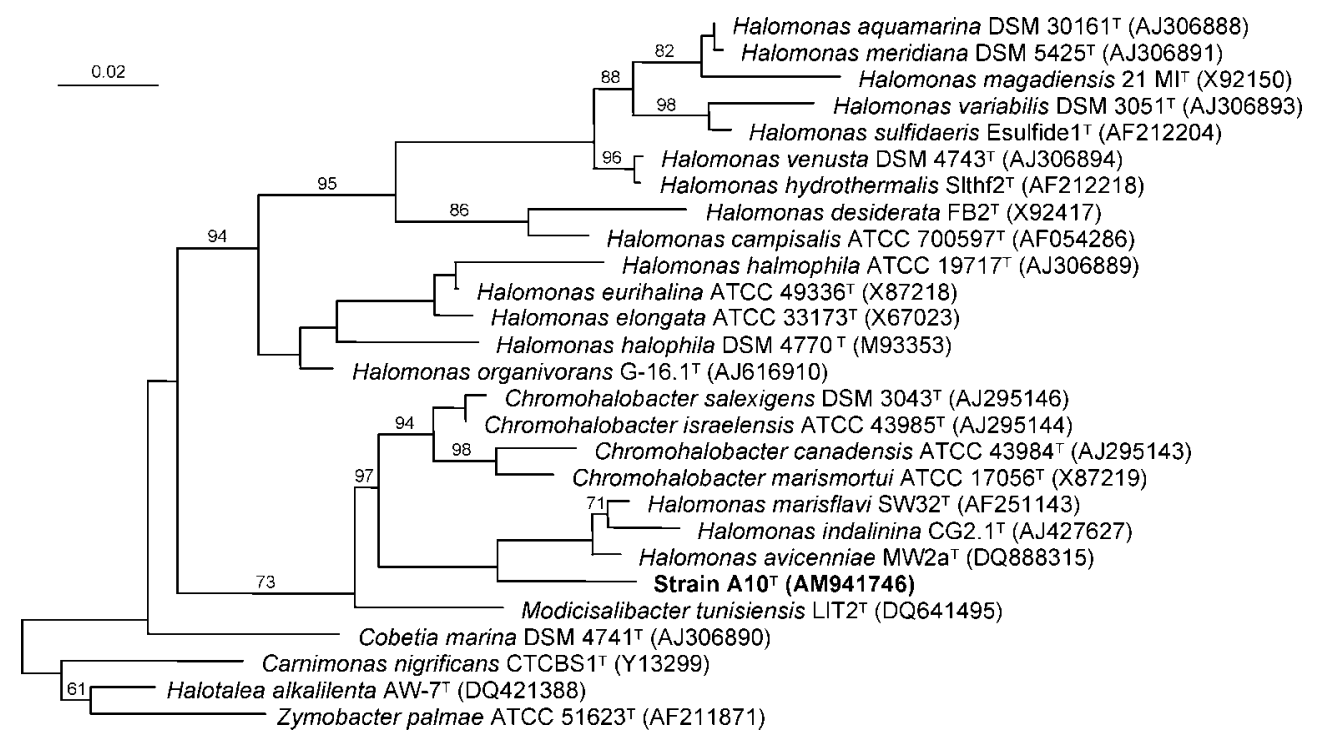

Fig. 1. Maximum-parsimony phylogenetic tree, based on $16 \mathrm{~S}$ rRNA gene sequences of strain $A 10^{\top}$ and closely related species. Sequence accession numbers used are shown in parentheses. Bootstrap values greater than $50 \%$ are indicated at branch points. Zymobacter palmae ATCC $51623^{\top}$ was used as an outgroup. Bar, $2 \%$ sequence divergence. 


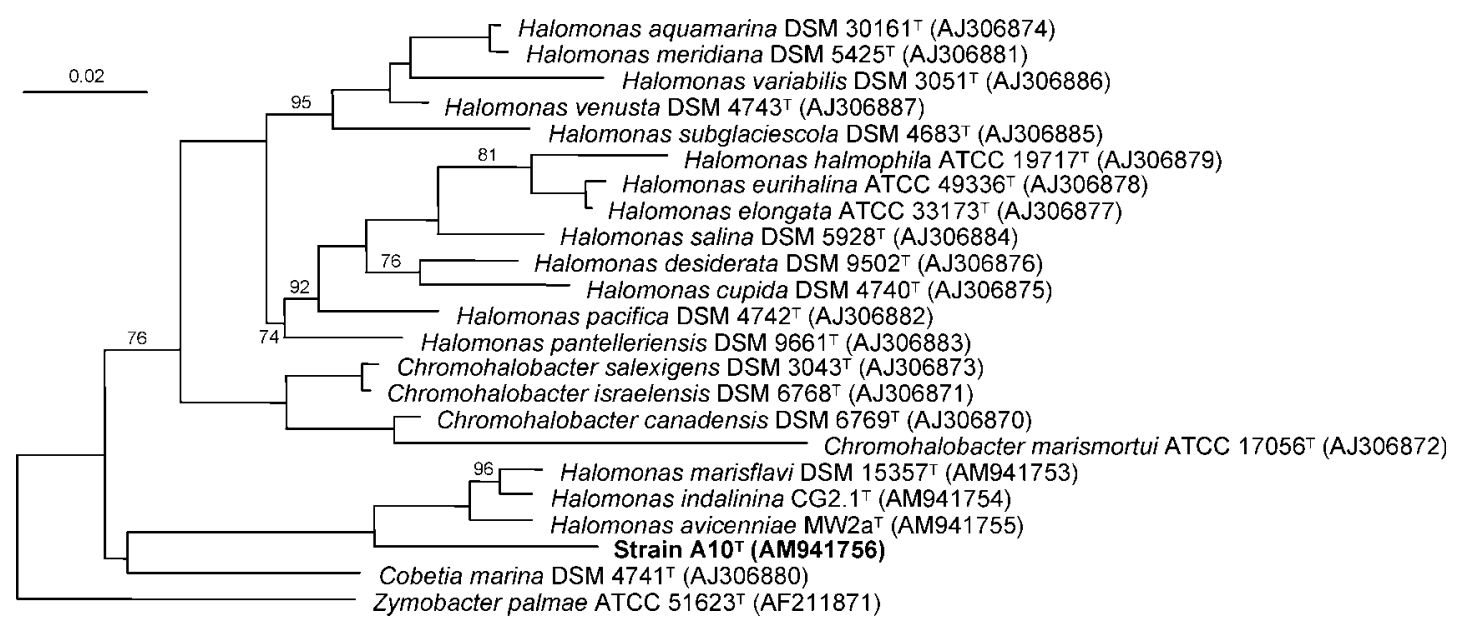

Fig. 2. Maximum-parsimony phylogenetic tree, based on $23 S$ rRNA gene sequences of strain $A 10^{\top}$ and closely related species. Sequence accession numbers used are shown in parentheses. Bootstrap values greater than $50 \%$ are indicated at branch points. Zymobacter palmae ATCC $51623^{\top}$ was used as an outgroup. Bar, $2 \%$ sequence divergence.

this family as to warrant their placement in a new genus. In fact, when we compared the $23 \mathrm{~S}$ rRNA gene sequences of strain $\mathrm{A}^{\mathrm{T}} \mathrm{T}^{\mathrm{T}}$ and those of Halomonas marisflavi DSM $15357^{\mathrm{T}}$, Halomonas indalinina CG2.1 ${ }^{\mathrm{T}}$ and Halomonas avicenniae $\mathrm{MW} 2 \mathrm{a}^{\mathrm{T}}$ with respect to other species of the most closely related genera, we obtained the following similarity values: $91.5-87.6 \%$ for other species of the genus Halomonas, $91.7-89.3 \%$ for species of Chromohalobacter, 91.7-89.8\% for Cobetia, 90.4-88.8\% for Zymobacter and $89.8-88.3 \%$ for Carnimonas.

The $\mathrm{G}+\mathrm{C}$ content of the genomic DNA was determined from the mid-point value $\left(T_{\mathrm{m}}\right)$ of the thermal denaturation profile (Marmur \& Doty, 1962) using the equation of Owen \& Hill (1979), as previously described in detail (Ventosa et al., 1999). The DNA G $+\mathrm{C}$ content of strain $\mathrm{A} 10^{\mathrm{T}}$ was $61.7 \mathrm{~mol} \%$, which is within the broad range described for species belonging to the genus Halomonas (52-68 mol\%) (Arahal \& Ventosa, 2005; Vreeland, 2005). However, this $\mathrm{G}+\mathrm{C}$ value was quite similar to those of the three closely related species of Halomonas, Halomonas marisflavi, Halomonas indalinina and Halomonas avicenniae (Table 1).

DNA-DNA hybridization studies were performed by using the competition procedure of the membrane method (Johnson, 1994), described in detail by Arahal et al. $(2001 \mathrm{a}, \mathrm{b})$. The hybridization temperature used was $56.9{ }^{\circ} \mathrm{C}$, which is within the limit of validity for the filter method (De Ley \& Tijtgat, 1970) and the percentage hybridization was calculated according to Johnson (1994). The experiments were carried out in triplicate. The levels of DNA-DNA relatedness between strain $\mathrm{A} 10^{\mathrm{T}}$ and Halomonas avicenniae $\mathrm{MW}^{\mathrm{T}} \mathrm{a}^{\mathrm{T}}$, Halomonas marisflavi DSM $15357^{\mathrm{T}}$ and Halomonas indalinina CG2.1 ${ }^{\mathrm{T}}$ were 21, 17 and $10 \%$, respectively. These levels of DNA-DNA relatedness were low enough to classify strain $A 10^{\mathrm{T}}$ as representing a genotypically distinct species (Stackebrandt \& Goebel, 1994; Stackebrandt et al., 2002).

Analysis of quinones and polar lipids was carried out by the Identification Service of the DSMZ (Braunschweig, Germany). The polar lipids detected for strain $\mathrm{A} 10^{\mathrm{T}}$ were phosphatidylglycerol, diphosphatidylglycerol, phosphatidylethanolamine, three different phospholipids of unknown structure, two glycolipids and an aminoglycolipid. This pattern was essentially the same as those found for Halomonas avicenniae MW $2 \mathrm{a}^{\mathrm{T}}$, Halomonas marisflavi DSM $15357^{\mathrm{T}}$ and Halomonas indalinina CG2.1 ${ }^{\mathrm{T}}$. Strain $\mathrm{A}^{\mathrm{T}}{ }^{\mathrm{T}}$ contained ubiquinone $9(\mathrm{Q} 9)$ as the major respiratory quinone $(95 \%)$, as well as ubiquinone $8(\mathrm{Q} 8)(5 \%)$ and traces of ubiquinone $10(\mathrm{Q} 10)$. The major respiratory quinones detected for Halomonas avicenniae $\mathrm{MW} 2 \mathrm{a}^{\mathrm{T}}$ were Q9 (99\%) and traces of Q8 and Q10, for Halomonas marisflavi DSM $15357^{\mathrm{T}}$ Q9 (92\%), Q8 (6\%) and Q10 (2\%) and for Halomonas indalinina CG2.1 ${ }^{\mathrm{T}}$ Q9 (93\%), Q8 (4\%) and Q10 (3\%). Thus, the polar lipids and respiratory quinones of strain $\mathrm{A} 10^{\mathrm{T}}$ were almost identical to those of the other three species; however, Q9 is typically also found in other members of the genus Halomonas (Arahal \& Ventosa, 2005; Vreeland, 2005; Arahal et al., 2007).

Fatty acids were analysed using GC (Kämpfer \& Kroppenstedt, 1996; Miller, 1982) at the BCCM/LMG, Gent, Belgium. Cells were cultured on SW10 medium at $\mathrm{pH} 7.0$ and $37^{\circ} \mathrm{C}$ for $24 \mathrm{~h}$. The predominant fatty acids of strain $\mathrm{A} 10^{\mathrm{T}}$ were $\mathrm{C}_{16: 0}, \mathrm{C}_{18: 1} \omega 7 c, \mathrm{C}_{19: 0}$ cyclo $\omega 8 c$ and $\mathrm{C}_{12: 0} 3-\mathrm{OH}$. This composition was very similar to those that we obtained under the same conditions for Halomonas avicenniae MW2 $\mathrm{a}^{\mathrm{T}}$, Halomonas marisflavi DSM $15357^{\mathrm{T}}$ and Halomonas indalinina CG2.1 $1^{\mathrm{T}}$, but some differences were observed with respect to Halomonas elongata ATCC $33173^{\mathrm{T}}$ (Table 2). However, this is a differential feature of the new 
Table 2. Cellular fatty acid compositions (\%) of strain $A 10^{\top}$ and closely related Halomonas species

Strains: 1, $\mathrm{A} 10^{\mathrm{T}}$ (Kushneria aurantia gen. nov., sp. nov.); 2, Halomonas avicenniae MW2 $\mathrm{a}^{\mathrm{T}} ; 3$, Halomonas indalinina CG2. ${ }^{\mathrm{T}} ; 4$, Halomonas marisflavi DSM $15357^{\mathrm{T}}$; 5 , Halomonas elongata ATCC $33173^{\mathrm{T}}$. - , Not detected.

\begin{tabular}{|lccccc|}
\hline Fatty acid & $\mathbf{1}$ & $\mathbf{2}$ & $\mathbf{3}$ & $\mathbf{4}$ & $\mathbf{5}$ \\
\hline $\mathrm{C}_{10: 0}$ & 1.1 & 1.0 & 1.6 & 2.4 & 4.7 \\
$\mathrm{C}_{10: 0} 3-\mathrm{OH}$ & - & - & - & - & 3.6 \\
$\mathrm{C}_{12: 0}$ & 0.8 & 0.8 & 0.8 & - & 4.7 \\
$\mathrm{C}_{12: 0}$ 2-OH & 0.4 & 3.2 & 3.6 & 3.2 & - \\
$\mathrm{C}_{12: 0} 3-\mathrm{OH}$ & 8.8 & 11.3 & 12.1 & 11.0 & 15.3 \\
$\mathrm{C}_{14: 0}$ & 1.9 & 0.4 & 0.7 & 0.5 & - \\
$\mathrm{C}_{16: 1} \omega 7 c^{\star}$ & 3.5 & 2.6 & 4.2 & 3.5 & 4.5 \\
$\mathrm{C}_{16: 0}$ & 40.4 & 37.4 & 40.7 & 33.4 & 25.6 \\
$\mathrm{C}_{16: 0} 3-\mathrm{OH}$ & - & - & - & - & 1.0 \\
$\mathrm{C}_{17: 0}$ cyclo & 0.9 & 3.2 & 2.2 & 2.6 & 1.6 \\
$\mathrm{C}_{18: 1} \omega 7 c$ & 28.4 & 16.6 & 20.0 & 25.7 & 25.6 \\
$\mathrm{C}_{18: 0}$ & 1.1 & 1.2 & 1.0 & 2.1 & 0.6 \\
$\mathrm{C}_{19: 0}$ cyclo $\omega 8 c$ & 11.8 & 22.3 & 12.9 & 15.7 & 10.6 \\
\hline
\end{tabular}

${ }^{\star}$ Included in summed feature $3\left(\mathrm{C}_{16: 1} \omega 7 c\right.$ and/or iso- $\left.\mathrm{C}_{15: 0} 2-\mathrm{OH}\right)$.

genus with respect to other genera of the Halomonadaceae (Table 3).

Overall, the phylogenetic data based on both the $16 \mathrm{~S}$ rRNA and $23 \mathrm{~S}$ rRNA gene sequence comparisons, the chemotaxonomic and genotypic results and the phenotypic features show clearly that strain $\mathrm{A} 10^{\mathrm{T}}$ constitutes a novel species and genus, separated from the genus Halomonas and other genera belonging to the Halomonadaceae, for which we propose the name Kushneria aurantia gen. nov., sp. nov. In addition, on the basis of the results reported we also propose to transfer the three species Halomonas marisflavi, Halomonas indalinina and Halomonas avicenniae to this new genus as Kushneria marisflavi comb. nov., Kushneria indalinina comb. nov. and Kushneria avicenniae comb. nov., respectively. The species of this new genus have all the 16S rRNA signature nucleotides characteristic of the family Halomonadaceae (Ben Ali Gam et al., 2007). Table 1 shows the differential features between the four species of Kushneria gen. nov. Some features that serve to differentiate this new genus from other genera of the family Halomonadaceae are shown in Table 3.

\section{Description of Kushneria gen. nov.}

Kushneria (Kush.ne'ri.a. N.L. fem. n. Kushneria from the name Kushner, honouring Dr Donn J. Kushner, a Canadian microbiologist who carried out pioneering studies on halophilic micro-organisms).

Cells are Gram-negative, motile rods. Endospores are not formed. Strictly aerobic. Catalase-positive and oxidasenegative. Halophilic; $\mathrm{Na}^{+}$is required for growth. Mesophilic. Chemo-organotrophic. The major respiratory quinone is Q9. Major fatty acids are $\mathrm{C}_{16: 0}, \mathrm{C}_{18: 1} \omega 7 c, \mathrm{C}_{19: 0}$ cyclo $\omega 8 c$ and $\mathrm{C}_{12: 0} 3-\mathrm{OH}$. Polar lipids are phosphatidylglycerol, diphosphatidylglycerol, phosphatidylethanolamine and unidentified phospholipids and glycolipids. The DNA G $+C$ content is $59.0-61.7 \mathrm{~mol} \%$. The genus Kushneria is a member of the family Halomonadaceae, phylogenetically related to Chromohalobacter and Halomonas. The type species is Kushneria aurantia.

\section{Description of Kushneria aurantia sp. nov.}

Kushneria aurantia (au.ran'ti.a. N.L. adj. aurantius orange; N.L. fem. adj. aurantia orange-pigmented).

Exhibits the following properties in addition to those given in the genus description. Cells are $1.0 \times 2.0-5.0 \mu \mathrm{m}$ in size and occur singly or in pairs. Does not produce exopolysaccharide and does not accumulate poly-hydroxyalkanoate. Colonies on SW10 medium after 2 days incubation at $37{ }^{\circ} \mathrm{C}$ are $0.5-1.0 \mathrm{~mm}$ in diameter, circular, smooth, regular and convex with an entire margin, with an orange pigmentation. Moderately halophilic, requires $\mathrm{NaCl}$; grows at $\mathrm{NaCl}$ concentrations in the range $5-17.5 \%(\mathrm{w} / \mathrm{v})$, with an optimum at $10 \%(\mathrm{w} / \mathrm{v}) \mathrm{NaCl}$. Growth occurs at temperatures of $20-40{ }^{\circ} \mathrm{C}$ (optimally at $37{ }^{\circ} \mathrm{C}$ ) and at pH 5.5-8.5 (optimally at $\mathrm{pH} 7.0-8.0$ ). Respiration with fumarate, nitrate and nitrite is negative. Gelatin and aesculin are hydrolysed. Positive for methyl red, phosphatase and Simmons' citrate tests. Starch, casein, Tween 80, tyrosine and DNA are not hydrolysed. Negative for $\mathrm{H}_{2} \mathrm{~S}$ production, Voges-Proskauer, indole production, nitrate and nitrite reduction, urease, arginine dihydrolase, phenylalanine deaminase, lysine decarboxylase, $\alpha$-galactosidase, $\alpha$ maltosidase, $N$-acetyl- $\beta$-glucosaminidase and L-aspartic acid arylamidase but positive for ornithine decarboxylase, $\beta$-galactosidase, $\alpha$-glucosidase and $\beta$-glucuronidase. Acid is produced from D-glucose, D-galactose, D-fructose, maltose, D-mannose and xylose, but not from arabinose, glycerol, mannitol, trehalose or sorbitol. Does not grow on MacConkey agar with $10 \%(\mathrm{w} / \mathrm{v})$ salts. The following compounds are used as sole carbon and energy sources: Dfructose, D-glucose, DL-malate, D-ribose, D-tartrate and Dxylose. The following compounds are not used as sole carbon and energy sources: aesculin, benzoate, ethanol, fumarate, hippurate, D-lactose, melezitose, salicin and starch. L-Cysteine is used as sole carbon, nitrogen and energy sources. The following compounds are not used as sole carbons, nitrogen and energy sources: L-isoleucine, DLlysine, L-methionine, L-tryptophan and L-valine. The following compounds are used (oxidized) as sole carbon and energy sources (Biolog): dextrin, glycogen, adonitol, Larabinose, D-arabitol, cellobiose, i-erythritol, D-fructose, Dgalactose, gentiobiose, $\alpha$-D-glucose, maltose, D-mannitol, D-mannose, D-psicose, D-sorbitol, trehalose, turanose, xylitol, succinic acid monomethyl ester, acetic acid, cisaconitic acid, citric acid, D-galacturonic acid, $\alpha$-ketoglutaric acid, DL-lactic acid, quinic acid, D-saccharic acid, succinic acid, bromosuccinic acid, succinamic acid, L-glutamic acid, 


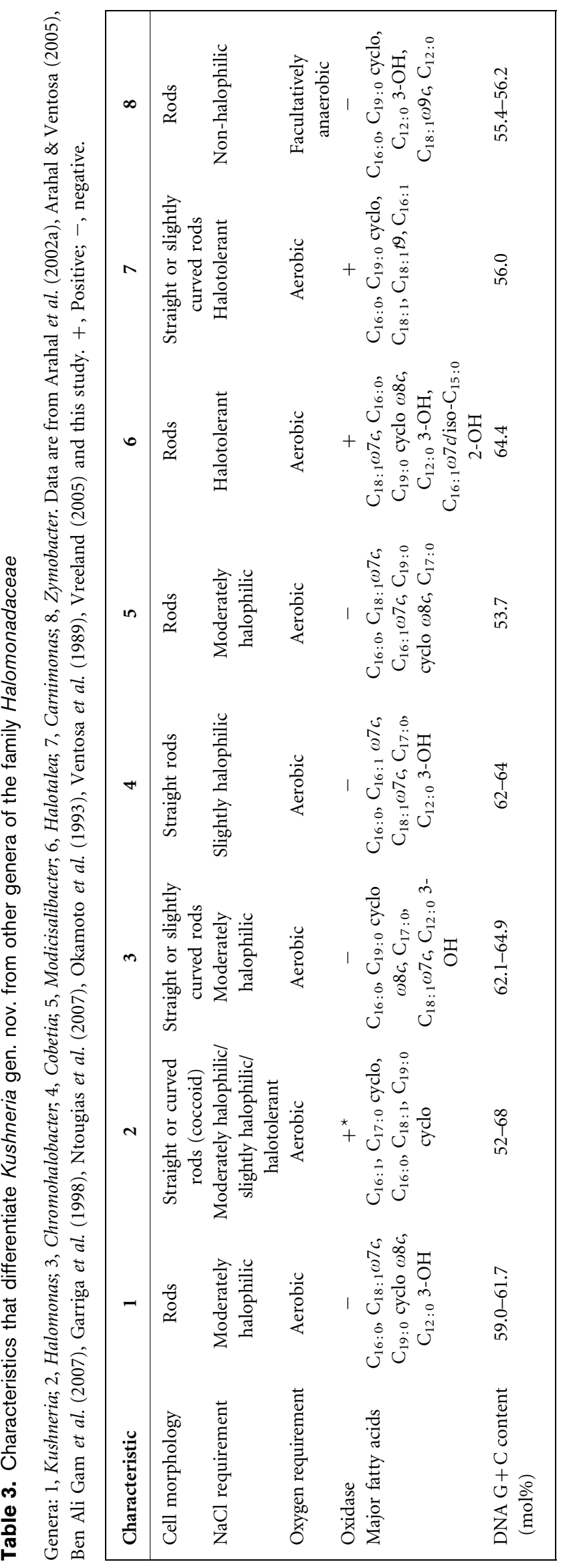

L-proline, L-pyroglutamic acid, L-serine, L-threonine, urocanic acid, inosine, uridine, thymidine, 2,3-butanediol, glycerol and D-glucose 6-phosphate. The following compounds are not used (oxidized) as sole carbon and energy sources (Biolog): $\alpha$-cyclodextrin, Tween 40, Tween 80, $N$ acetyl-D-galactosamine, $N$-acetyl-D-glucosamine, L-fucose, myo-inositol, $\alpha$-D-lactose, lactulose, D-melibiose, methyl $\alpha$ D-glucoside, D-raffinose, L-rhamnose, sucrose, pyruvic acid methyl ester, formic acid, D-galactonic acid lactone, D-gluconic acid, D-glucosaminic acid, D-glucuronic acid, $\alpha$-hydroxybutyric acid, $\beta$-hydroxybutyric acid, $\gamma$-hydroxybutyric acid, $p$-hydroxyphenylacetic acid, itaconic acid, $\alpha$-ketobutyric acid, $\alpha$-ketovaleric acid, malonic acid, propionic acid, sebacic acid, glucuronamide, alaninamide, D-alanine, L-alanine, L-alanyl-glycine, L-asparagine, Laspartic acid, glycyl L-aspartic acid, glycyl L-glutamic acid, L-histidine, hydroxy-L-proline, L-leucine, L-ornithine, Lphenylalanine, D-serine, DL-carnitine, $\gamma$-aminobutyric acid, phenylethylamine, putrescine, 2-aminoethanol, DL- $\alpha$ glycerol phosphate and $\alpha$-D-glucose 1-phosphate. Resistant to ( $\mu \mathrm{g}$ per disc, unless specified otherwise): bacitracin (10 U), cephalothin (30), erythromycin (15), kanamycin (30), nalidixic acid (30) and streptomycin (10). Susceptible to chloramphenicol (30), novobiocin (30), penicillin $\mathrm{G}(10 \mathrm{U})$, polymyxin $\mathrm{B}$ (300 U), rifampicin (5), sulfamethazole/trimethoprim (23.75/1.25) and vancomycin (30). The DNA G+C content of the type strain is $61.7 \mathrm{~mol} \%$.

The type strain, $\mathrm{A} 10^{\mathrm{T}}\left(=\mathrm{CCM} 7415^{\mathrm{T}}=\mathrm{CECT} 7220^{\mathrm{T}}\right)$, was isolated from the leaf surface of $A$. germinans (black mangrove).

\section{Description of Kushneria marisflavi comb. nov.}

Kushneria marisflavi (ma.ris.fla'vi. L. gen. neut. n. maris of the sea; L. neut. adj. flavum yellow; L. gen. neut. n. marisflavi of the Yellow Sea, Korea).

Basonym: Halomonas marisflavi Yoon et al. 2001.

The description is the same as that for Halomonas marisflavi (Yoon et al. 2001), with the addition that the polar lipids are phosphatidylglycerol, diphosphatidylglycerol, phosphatidylethanolamine, aminoglycolipid and an unidentified phospholipid and a glycolipid.

The type strain is $\mathrm{SW} 32^{\mathrm{T}} \quad\left(=\mathrm{DSM} \quad 15357^{\mathrm{T}}=\mathrm{JCM}\right.$ $10873^{\mathrm{T}}=$ KCCM $80003^{\mathrm{T}}$ ).

\section{Description of Kushneria indalinina comb. nov.}

Kushneria indalinina (in.da.li.ni'na. N.L. n. indalo -inis a prehistoric magical symbol; L. suff. -inis-a-um suffix used in the sense of 'belonging to'; N.L. fem. adj. indalinina pertaining to the Indalo, the symbol of the province of Almería, Spain, from where the type strain was isolated).

Basonym: Halomonas indalinina Cabrera et al. 2007.

The description is the same as that for Halomonas indalinina (Cabrera et al., 2007), with the addition that 
the polar lipids are phosphatidylglycerol, diphosphatidylglycerol, phosphatidylethanolamine, aminoglycolipid and an unidentified phospholipid and a glycolipid. The major respiratory quinone is Q9.

The type strain is CG2.1 ${ }^{\mathrm{T}}\left(=\mathrm{CECT} 5902^{\mathrm{T}}=\mathrm{CIP} 109528^{\mathrm{T}}=\right.$ LMG $23625^{\mathrm{T}}$ ).

\section{Description of Kushneria avicenniae comb. nov.}

Kushneria avicenniae [a.vi.cen.ni'ae. N.L. n. Avicennia scientific name of a botanical genus which encompasses Avicennia germinans (the black mangrove); N.L. gen. n. avicenniae of Avicennia, isolated from leaves of Avicennia germinans].

Basonym: Halomonas avicenniae Soto-Ramírez et al. 2007.

The description is the same as that for Halomonas avicenniae (Soto-Ramírez et al. 2007), with the addition that the polar lipids are phosphatidylglycerol, diphosphatidylglycerol, phosphatidylethanolamine, aminoglycolipid and an unidentified phospholipid and a glycolipid. The major respiratory quinone is Q9.

The type strain is MW2 $\mathrm{a}^{\mathrm{T}}\left(=\right.$ CECT $7193^{\mathrm{T}}=$ CIP $109711^{\mathrm{T}}=$ CCM $7396^{\mathrm{T}}$ ).

\section{Acknowledgements}

This study was supported by grants from the Spanish Ministerio de Educación y Ciencia (project BIO2006-006927), from the Junta de Andalucía (project P06-CVI-01829), and by the Dean of Arts and Sciences Seed Money Program at the University of Puerto RicoMayagüez Campus and the University of Puerto Rico AlaCiMa Program.

\section{References}

Arahal, D. R. \& Ventosa, A. (2005). The family Halomonadaceae. In The Prokaryotes: an Evolving Electronic Resource for the Microbiological Community, 3rd edn, release 3.20. Edited by M. Dworkin. New York: Springer.

Arahal, D. R., García, M. T., Ludwig, W., Schleifer, K. H. \& Ventosa, A. (2001a). Transfer of Halomonas canadensis and Halomonas israelensis to the genus Chromohalobacter, as Chromohalobacter canadensis comb. nov. and Chromohalobacter israelensis comb. nov. Int J Syst Evol Microbiol 51, 1443-1448.

Arahal, D. R., García, M. T., Vargas, C., Cánovas, D., Nieto, J. J. \& Ventosa, A. (2001b). Chromohalobacter salexigens sp. nov., a moderately halophilic species that includes Halomonas elongata DSM 3043 and ATCC 33174. Int J Syst Evol Microbiol 51, 1457-1462.

Arahal, D. R., Castillo, A. M., Ludwig, W., Schleifer, K. H. \& Ventosa, A. (2002a). Proposal of Cobetia marina gen. nov., comb. nov., within the family Halomonadaceae, to include the species Halomonas marina. Syst Appl Microbiol 25, 207-211.

Arahal, D. R., Ludwig, W., Schleifer, K. H. \& Ventosa, A. (2002b). Phylogeny of the family Halomonadaceae based on 23S and $16 \mathrm{~S}$ rDNA sequence analyses. Int J Syst Evol Microbiol 52, 241-249.

Arahal, D. R., Vreeland, R. H., Litchfield, C. D., Mormile, M. R., Tindall, B. J., Oren, A., Bejar, V., Quesada, E. \& Ventosa, A. (2007).
Recommended minimal standards for describing new taxa of the family Halomonadaceae. Int J Syst Evol Microbiol 57, 2436-2446.

Bauer, A. W., Kirby, W. M. M., Sherris, J. C. \& Turck, M. (1966). Antibiotic susceptibility testing by a standarized single disk method. Am J Clin Pathol 45, 493-496.

Ben Ali Gam, Z., Abdelkafi, S., Casalot, L., Tholozan, J. L., Oueslati, R. \& Labat, M. (2007). Modicisalibacter tunisiensis gen. nov., sp. nov., an aerobic, moderately halophilic bacterium isolated from an oilfieldwater injection sample, and emended description of the family Halomonadaceae Franzmann et al. 1989 emend Dobson and Franzmann 1996 emend. Ntougias et al. 2007. Int J Syst Evol Microbiol 57, 2307-2313.

Cabrera, A., Aguilera, M., Fuentes, S., Incerti, C., Russell, N. J., Ramos-Cormenzana, A. \& Monteoliva-Sánchez, M. (2007). Halomonas indalinina sp. nov., a moderately halophilic bacterium isolated from a solar saltern in Cabo de Gata, Almería, southern Spain. Int J Syst Evol Microbiol 57, 376-380.

Cowan, S. T. \& Steel, K. J. (1965). Manual for the Identification of Medical Bacteria. London: Cambridge University Press.

De Ley, J. \& Tijtgat, R. (1970). Evaluation of membrane filter methods for DNA-DNA hybridization. Antonie van Leeuwenhoek 36, 461-474.

Dussault, H. P. (1955). An improved technique for staining redhalophilic bacteria. J Bacteriol 70, 484-485.

Franzmann, P. D., Wehmeyer, U. \& Stackebrandt, E. (1988). Halomonadaceae fam. nov., a new family of the class Proteobacteria to accommodate the genera Halomonas and Deleya. Syst Appl Microbiol 11, 16-19.

Garriga, M., Ehrmann, M. A., Arnau, J., Hugas, M. \& Vogel, R. F. (1998). Carnimonas nigrificans gen. nov., sp. nov., a bacterial causative agent for black spot formation on cured meat products. Int J Syst Bacteriol 48, 677-686.

Johnson, J. L. (1994). Similarity analysis of DNAs. In Methods for General and Molecular Bacteriology, pp. 655-681. Edited by P. Gerhardt, R. G. E. Murray, W. A. Wood \& N. R. Krieg. Washington, DC: American Society for Microbiology.

Kämpfer, P. \& Kroppenstedt, R. M. (1996). Numerical analysis of fatty acid patterns of coryneform bacteria and related taxa. Can J Microbiol 42, 989-1005.

Koser, S. A. (1923). Utilization of the salts of organic acids by the colon-aerogenes group. J Bacteriol 8, 493-520.

Ludwig, W., Strunk, O., Klugbauer, S., Klugbauer, N., Weizenernegger, M., Neumaier, J., Bachleitner, M. \& Schleifer, K.-H. (1998). Bacterial phylogeny based on comparative sequence analysis. Electrophoresis 19, 554-568.

Ludwig, W., Strunk, O., Westram, R., Richter, L., Meier, H., Yadhukumar, Buchner, A., Lai, T., Steppi, S. \& other authors (2004). ARB: a software environment for sequence data. Nucleic Acids Res 32, 1363-1371.

Lugo, A. E. \& Snedaker, S. C. (1975). Properties of a mangrove forest in southern Florida. In Actas, International Symposium on Biological Management of Mangroves, pp. 170-212. Edited by G. Walsh, S. C. Snedaker \& H. Teas. Gainesville: University of Florida.

Marmur, J. (1961). A procedure for the isolation of deoxyribonucleic acid from microorganisms. J Mol Biol 3, 208-218.

Marmur, J. \& Doty, P. (1962). Determination of the base composition of deoxyribonucleic acid from its thermal denaturation temperature. $J$ Mol Biol 5, 109-118.

Mata, J. A., Martínez-Cánovas, J., Quesada, E. \& Béjar, V. (2002). A detailed phenotypic characterisation of the type strains of Halomonas species. Syst Appl Microbiol 25, 360-375. 
Mellado, E., Moore, E. R. B., Nieto, J. J. \& Ventosa, A. (1995). Phylogenetic inferences and taxonomic consequences of $16 \mathrm{~S}$ ribosomal DNA sequence comparison of Chromohalobacter marismortui, Volcaniella eurihalina, and Deleya salina and reclassification of $V$. eurihalina as Halomonas eurihalina comb. nov. Int J Syst Bacteriol 45, 712-716.

Miller, L. T. (1982). Single derivation method for routine analysis of bacterial whole-cell fatty acid methyl esters, including hydroxyl acids. J Clin Microbiol 16, 584-586.

Nieto, J. J., Fernández-Castillo, R., Márquez, M. C., Ventosa, A., Quesada, E. \& Ruiz-Berraquero, F. (1989). Survey of metal tolerance in moderately halophilic eubacteria. Appl Environ Microbiol 55, 23852390.

Ntougias, S., Zervakis, G. I. \& Fasseas, C. (2007). Halotalea alkalilenta gen. nov., sp. nov., a novel osmotolerant and alkalitolerant bacterium from alkaline olive mill wastes, and emended description of the family Halomonadaceae Franzmann et al. 1989, emend. Dobson and Franzmann 1996. Int J Syst Evol Microbiol 57, 1975-1983.

Okamoto, T., Taguchi, H., Nakamura, K., Ikenaga, H., Kuraishi, H. \& Yamasato, K. (1993). Zymobacter palmae gen. nov., sp. nov., a new ethanol-fermenting peritrichous bacterium isolated from palm sap. Arch Microbiol 160, 333-337.

Owen, R. J. \& Hill, L. R. (1979). The estimation of base compositions, base pairing and genome sizes of bacterial deoxyribonucleic acids. In Chemical Methods for Microbiologists, pp. 277-296. Edited by F. A. Skinner \& D. W. Lovelock. London: Academic Press.

Quesada, E., Ventosa, A., Ruiz-Berraquero, F. \& RamosCormenzana, A. (1984). Deleya halophila, a new species of moderately halophilic bacteria. Int J Syst Bacteriol 34, 287-292.

Sehgal, S. N. \& Gibbons, N. E. (1960). Effect of some metal ions on the growth of Halobacterium cutirubrum. Can J Microbiol 6, 165-169.

Soto-Ramírez, N., Sánchez-Porro, C., Rosas, S., González, W., Quiñones, M., Ventosa, A. \& Montalvo-Rodríguez, R. (2007). Halomonas avicenniae sp. nov., isolated from the salty leaves of the black mangrove Avicennia germinans in Puerto Rico. Int J Syst Evol Microbiol 57, 900-905.

Soto-Ramírez, N., Sánchez-Porro, C., Rosas-Padilla, S., Almodóvar, K., Jiménez, G., Machado-Rodríguez, M., Zapata, M., Ventosa, A. \&
Montalvo-Rodríguez, R. (2008). Halobacillus mangrovi sp. nov., a moderately halophilic bacterium isolated from the black mangrove Avicennia germinans. Int J Syst Evol Microbiol 58, 125-130.

Stackebrandt, E. \& Goebel, B. M. (1994). Taxonomic note: a place for DNA-DNA reassociation and 16S rRNA sequence analysis in the present species definition in bacteriology. Int J Syst Bacteriol 44, 846849.

Stackebrandt, E., Fredericksen, W., Garrity, G. M., Grimont, P. A. D., Kämpfer, P., Maiden, M. C. J., Nesme, X., Rosselló-Mora, R., Swings, J. \& other authors (2002). Report of the ad hoc committee for the re-evaluation of the species definition in bacteriology. Int $J$ Syst Evol Microbiol 52, 1043-1047.

Ventosa, A., Quesada, E., Rodríguez-Valera, F., Ruiz-Berraquero, F. \& Ramos-Cormenzana, A. (1982). Numerical taxonomy of moderately halophilic Gram-negative rods. J Gen Microbiol 128, 19591968.

Ventosa, A., Gutierrez, M. C., Garcia, M. T. \& Ruiz-Berraquero, F. (1989). Classification of Chromobacterium marismortui in a new genus, Chromohalobacter gen. nov., as Chromohalobacter marismortui comb. nov., nom. rev. Int J Syst Bacteriol 39, 382-386.

Ventosa, A., Nieto, J. J. \& Oren, A. (1998). Biology of moderately halophilic aerobic bacteria. Microbiol Mol Biol Rev 62, 504-544.

Ventosa, A., Gutierrez, M. C., Kamekura, M. \& Dyall-Smith, M. L. (1999). Proposal to transfer Halococcus turkmenicus, Halobacterium trapanicum JCM 9743 and strain GSL-11 to Haloterrigena turkmenica gen. nov., comb. nov. Int J Syst Bacteriol 49, 131-136.

Vreeland, R. H. (2005). Genus I. Halomonas. In Bergey's Manual of Systematic Bacteriology, 2nd edn, vol. 2, pp. 300-313. Edited by D. J. Brenner, N. R. Krieg, J. T. Staley \& G. M. Garrity. New York: Springer.

Vreeland, R. H., Litchfield, C. D., Martin, E. L. \& Elliot, E. (1980). Halomonas elongata, a new genus and species of extremely salt tolerant bacteria. Int J Syst Bacteriol 30, 485-495.

Yoon, J.-H., Choi, S. H., Lee, K.-C., Kho, Y. H., Kang, K. H. \& Park, Y.-H. (2001). Halomonas marisflavae sp. nov., a halophilic bacterium isolated from the Yellow Sea in Korea. Int J Syst Evol Microbiol 51, 1171-1177. 